\title{
BAKARKÖR BUZAĞI VE DANALARDA SERUM VE KARACİGER İZ ELEMENT (Zn, Cu, Mn) DÜZEYLERI*
}

Serum and Liver Levels of Trace Elements $(\mathrm{Zn}, \mathrm{Cu}, \mathrm{Mn})$ in Amaurotic Calves.

Summary: In this study, it was aimed to investigate, in the birth cases of amaurotic calves frequently observed in Niğde county, a city in Central Anatolia and its surroundings, the probable relationship between amaurosis and the serum and liver levels of trace elements.

In this research, trace element levels were measured using atomic absorption spectrophotometry (AAS) in the serum samples of 39 amaurotic and 15 normal calves and in the liver samples of 10 amaurotic calves and 7 normal young cattle taken from the region.

Serum $\mathrm{Zn}, \mathrm{Cu}$ and $\mathrm{Mn}$ mean levels were found as follows respectively: In the normal calves $1.507 \pm 0.133,0.951 \pm 0.051$ and $0.088 \pm 0.017 \mathrm{ppm}$ and in the amaurotic calves $1.054 \pm 0.053,0.731 \pm 0.033$ and $0.135 \pm 0.01 \mathrm{ppm}$. It was seen that, in the amaurotic calves, serum $\mathrm{Zn}$ and $\mathrm{Cu}$ mean levels significantly decreased $(p<0.001)$, whereas serum Mn mean levels sifnificantly increased $(p<0.05)$. A significant positive correlation $(p<0.05)$ was found between the serum $\mathrm{Zn}$ and $\mathrm{Cu}$ levels.

The changes in the serum trace elements levels were suggested to originate from feeding the calves and libitum with the roots, leaves and knots of potato plant rich in nitrates and nitrites which are the basic cause of the vit-A deficiency seen in calves, and probably rich in phytates.

As a solution to the problem, it was suggested to remove the roots, leaves and knots of potato plant completely or partly from ration.

Özet: Bu çalşmada, Niğde ili ve çevresinde sık rastlanan kör buză̆ı doğumu olgularında, bakarkörlü̆̆̈̈n (Amaurosis = Blindness) serum ve karaciğer iz

* Aynı adlı doktora tezinden özetlenmiștir.

1. Dr. Veteriner Hekim, Güçlükaya Mah. Çekirge Cad. 34/4 Keçiören-ANKARA.

2. Doç. Dr. A.Ü. Veteriner Fakültesi, Biyokimya Anabilim Dalı 06110 Ankara-TÜRKIYYE. 
element ( $\mathrm{Zn}, \mathrm{Cu}, \mathrm{Mn})$ düzeyleri ile olan muhtemel ilişkisinin incelenmesi amaçlanmıştır.

Araştırmada, bölgeden temin edilen 39 bakarkör, 15 normal buzağıya ait serum örneklerinde ve 10 bakarkör buzağı, 7 normal danaya ait karaciğer örneklerinde iz element düzeyleri atomik absorpsiyon spektrofotometrik yöntemle (AAS) tayin edilmistir.

Serum $\mathrm{Zn}, \mathrm{Cu}$ ve Mn ortalama düzeyleri normal buză̆ılarda sirasıyla $1.507 \pm 0.133,0.951 \pm 0.051$ ve $0.088 \pm 0.017$ ppm, bakarkör buzağılarda sirasiyla $1.054 \pm 0.053,0.731 \pm 0.033$ ve $0.135 \pm 0.01 \mathrm{ppm}$ olarak hesaplanmıştır. Bakarkör hayvanlarda serum $\mathrm{Zn}$ ve $\mathrm{Cu}$ ortalama düzeylerinin önemli derecede düştü̆̈̈̈ $(p<0.001)$, serum Mn ortalama düzeylerinin ise önemli derecede yükseldiği $(p<0.05)$ tespit edilmiştir. Serum $\mathrm{Zn}$ ve $\mathrm{Cu}$ değerleri arasında önemli derecede $(p<0.05)$ pozitif bir korrelasyonun varlığı saptanmıstır.

Bakarkör hayvanlarda serum iz element düzeylerinde meydana gelen değ sikliklerin, hayvanlarda varlığl tesbit edilen vit-A yetersizliğinin esas nedenini teşkil eden nitrat ve nitritler ile muhtemelen fitatlardan zengin olan patates bitkisinin kök, yaprak ve yumrularının ad libitum verilmesinden kaynaklanabileceği sonucuna varilmıstır.

Hayvanların rasyondaki bazı besin maddelerinden yararlanması üzerine olumsuz etki yapan patates bitkisinin değişik kısımlarının ya rasyondan tama. men f̧ıkarılması ya da sınırlı olarak verilmesi probleme çözüm olarak önerilebilir.

\section{Giriş}

Organizmanın fonksiyonlarını yerine getirebilmesi ve bunu sağlıklı bir şekilde sürdürebilmesi için protein, yağ, karbonhidrat, amino asit ve mineral tuzlar gibi temel besin ve yapı maddeleri ile beraber vitaminlerin ve iz elementlerin de düzenli bir şekilde ve yeterli miktarda alınması gereklidir.

İnorganik elementlerin organizmadaki işlevlerinin, birbirleri arasındaki ilişkilerin, verime olan etkilerinin ve yetersizliklerinde veya fazla tüketilmesinde ortaya çıkabilecek aksaklıkların bilinmesi rasyonel hayvan beslemenin bir gereğidir. Bakteriyel, viral ve paraziter hastalıklar yanında mineral madde fazlalık ve yetersizlik. hastalıkları hiç de küçümsenmeyecek derecede verim düşüklüklerine yol açarak ülke ekonomisinde büyük kayıplara neden olabilmektedir (37).

Hayvan organizmasında başta görme olayı olmak üzere büyüme ve gelişme, üreme, embriyonik gelişme ve karbonhidrat metabolizmasında rol oynayan vit.A'nın yetersizliklerinde çeşitli çiftlik hayvanlarında bakarkörlük (amaurosis=blindness), kemik gelişiminde gerileme ve ağırlık artışının yavaşlaması ile seyreden Hipovitaminoz A olguları bildirilmiştir (1, 2, 8, 13, 31, 33, 34, 36). 
Vit-A'nın taşınması ve kullanımında, seksüel ve somatik gelişmede çinkonun önemli rolü vardır (11). Ayrıca vit-A'nın karaciğerden normal bırakılımı ve kandaki normal konsantrasyonlarının sürdürülmesi için de çinko gereklidir (4, 32).

Çinkonun boğalarda plazma ve karaciğer retinol konsantrasyonlarını kısmen artırdığı bildirilmiştir (27).

Çinko metabolizması üzerinde vit-A'nın etkili olduğu ve retinil asetanın çinkonun ince barsakdaki akümülasyon ve transportunu artırdığı rapor edilmiştir (3).

Gelişme dönemindeki domuzlarda retinol bağlayıcı protein (RBP) sentezinin bozulması sonucu oluşan vit-A noksanlıklarının enerji, protein veya $\mathrm{Zn}$ yetersizliğinin bir indikatörü olabileceği bildirilmiştir (30).

Deneysel A-avitaminoz oluşturulan civcivlerde buna bağh ikincil bir $\mathrm{Zn}$ yetersizliği meydana geldiği bildirilmiştir (3). Vit-A yetersizliğine bağlı olarak barsak mukozasında $\mathrm{Zn}$ emilimi azalmakta ve serum $\mathrm{Zn}$ konsantrasyonlan düşmektedir. Retinil asetat ilavesiyle $\mathrm{Zn}$ emilimi tam olarak normale dönmektedir. Bu olayda $\mathrm{Zn}$ dengesi negatif olup dokularda $\mathrm{Zn}$ düzeyi azalmıştır (3).

Vit-A ve $\mathrm{Zn}$ yetersizliği birlikte bulunan kuzularda vit-A tedavisinin maksimum etkisi için Zn ilavesi gereklidir (32).

Rasyonun $\mathrm{Cu}$ ve $\mathrm{Zn}$ düzeyleri arasında belli bir oranın bulunması gerektiğ bilinmektedir (24). Bu oran ruminantlar için 1/10 olarak önerilmektedir (7). Buhlardan birinin miktarı diğerinin aleyhine artacak olursa diğerinin absorbsiyonu engellenir ve yetersizliğe neden olabilir (37).

Bakırın önemli işlevlerinden biri merkezi sinir sisteminin normal kuruluş ve işlevini sağlaması olup yetersizliğinde sinir sisteminin myelin yapısı bozulmakta ve demyelinizasyon oluşmaktadır $(25,38)$.

Bakarkörlük olgularında fena kemik teşekkülü ve bununla ilgili olarak foramen opaticus'un daralması sonucu görme sinirinin basınç altında kalışı, körlüğün temel bir nedeni olduğu ileri sürülmektedir $(5,12,40)$.

Osteoklastik aktivitede vit-A kadar Zn'nun da rolü vardır. Çinkonun yetersizliği civcivlerde kemiklerin kalınlaşması ve kısalığı, buzağılarda ise kol ve bacak deformitelerine sebep olur (13).

Normal kemik gelişimi için gerekli olan $(11,25)$ Cu'ın yetersizliğinde gençlerde raşitizm ve yaşlılarda osteomalasi şeklinde görülen kemikleşme bozuklukları kaydedilmiştir $(10,28)$.

Yavrunun rahim içinde gelişmesi (29), büyüme, üreme ve iskelet gelişimi için bütün hayvan türlerinde gerekli olan $(6,26)$ Mn'ın yetersizliğinde fena kemik teşekkülü bildirilmiştir (41). 
Yukarıda bahsedilen foramen opticus daralmasında serum ya da karaciğer $\mathrm{Zn}, \mathrm{Cu}$ ve $\mathrm{Mn}$ düzeylerinin etkili olabileceği düşünülebilir.

Niğde İli ve çevresinde kör buzağı doğumlanına sıklıkla rastlanmaktadır. Bozukluğun bölgede aşın gübrelemeye bağlı olarak gelişen kronik nitrat toksikasyonu sonucu şekillenen hipovitaminoz-A ile ilgili olduğu tespit edilmiş (1) ve gerçekten de yörede fazlaca üretilen ve hayvanlara ad libitum verilen patates bitkisinin değişik kısımlanında yükssek nitrat varlığı saptanmıştır (42).

Bu çalışmada ise, yöreden temin edilen aynı hayvan materyali üzerinde ve literatür bilgiler ışığında, bakarkörlüğün serum ve karaciğer iz element $(\mathrm{Zn}, \mathrm{Cu}, \mathrm{Mn})$ düzeyleri ile olan muhtemel ilişkisinin incelenmesi ve elde edilecek sonuçların klinik olarak uygulanabilirliğinin tartışılması amaçlanmıştir.

\section{Materyal ve Metod}

Niğde ili ve çevresinden sağlanan 39 adet bakarkör ve 15 adet normal buzağıya ait kan serumları çalışmamızın materyalini oluşturmuştur. Ayrıca bakarkör 10 buzağıya otopsi yapılarak karaciğer örnekleri de alınmışır. Normal buzağı kesiminin yasak olmasından dolayı 1-2 yaş arasında 7 adet normal danaya ait karaciğer örneği Niğde ili mezbahasından temin edilmiştir.

Bakarkör ve normal buzağıların vena jugularislerinden alınan kan, daha önce usulüne uygun olarak temizlenmiş santrifüj tüplerine alınmıştır. Pıhtılaşan kanlardan elde edilen serumlar iz element tayinine kadar $-20^{\circ} \mathrm{C}$ de dondurularak saklanmışır. Elde edilen bakarkör buzağı ve normal dana karaciğerleri iz element tayinine kadar temiz naylon poşetlerde $-20^{\circ} \mathrm{C}$ de dondurularak muhafaza edilmiştir.

Serum ve karaciğer $\mathrm{Zn}, \mathrm{Cu}$ ve $\mathrm{Mn}$ analizleri atomik absorpsiyon spektrofotometrik olarak gerçekleştirilmiştir (39).

Elde edilen gruplararası ortalama değerin isetatistik önemliliği için "t-testi" ve parametreler arası ilişki için korrelasyon analizi uygulanmıştır (18).

\section{Bulgular}

Bakarkör ve normal buzağılara ait serum ortalama değerleri ve istatistik önemliliği Tablo-1'de, bakarkör buzağı ve normal danalara ait karaciğer ortalama değerleri Tablo-2'de gösterilmiştir.

Serum ve Karaciğer iz element düzeyleri arasındaki korrelasyonlar Tablo-3 ve 4'de sunulmuştur. Bakarkör buzağılara ait serum $\mathrm{Zn}$ ve $\mathrm{Cu}$ düzeylerinin sıklık dağılımı Tablo-5'de düzenlenmiştir. 
Serum $\mathrm{Zn}$ ve $\mathrm{Cu}$ ortalama değerleri normal buzağılarda sırasıyla $1.507 \pm 0.133$ ve $0.951 \pm 0.051 \mathrm{ppm}$, bakarkör buzağılarda ise sirasıyla $1.054 \pm 0.053$ ve $0.731 \pm 0.033 \mathrm{ppm}$ olarak hesaplanmıştır. Gruplararası farklılıklar istatistiksel açıdan önemli bulunmuştur $(p<0.001)$. Bakarkör hayvanlarda $\mathrm{Zn}$ ve $\mathrm{Cu}$ ortalama düzeyleri sırasıyla $\% 30$ ve $\% 23$ oranında düşük bulunmuştur. Buna karşın, serum Mn düzeyleri, bakarkör hayvanlarda normallere göre \%53 oranında artı̧̧ göstermiştir. Bu artışın istatistik önemli olduğu $(\mathrm{p}<0.05)$ hesaplanmıştır (Tablo-1).

Bakarkör ve normal buzağılarda serum $\mathrm{Zn}$ ve $\mathrm{Cu}$ değerleri arasında önemli derecede $(\mathrm{p}<0.05)$ pozitif bir korrelasyonun varlığı tespit edilmiştir (Tablo-3). Bu ilişkinin bakarkör buzağılarda zayıflamış olduğu görülmektedir.

Bakarkör hayvanlara ait serum ve karaciğer $\mathrm{Zn}, \mathrm{Cu}$ ve $\mathrm{Mn}$ düzeyleri arasında bir ilişkinin varlığı saptanamamıştır (Tablo-4).

Tablo 1. Bakarkör ve Normal Buzağılarda Serum, Zn, Cu ve Mn Ortalama Düzeyleri (ppm)

Table 1. The average serum $\mathrm{Zn}, \mathrm{Cu}$ and $\mathrm{Mn}$ levels in normal and blindness calves (ppm).

\begin{tabular}{|c|c|c|c|c|}
\hline & & $\mathrm{Zn}$ & $\mathrm{Cu}$ & $M n$ \\
\hline & $\mathrm{n}$ & $\bar{X} \pm S \bar{x}$ & $\bar{X}_{ \pm} S \bar{x}$ & $\bar{x} \pm S \bar{x}$ \\
\hline Bakarkör & 39 & $1.054 \pm 0.053$ & $0.731 \pm 0.033$ & $0.135 \pm 0.010$ \\
\hline Normal & 15 & $1.507 \pm 0.133$ & $0.951 \pm 0.051$ & $0.088 \pm 0.017$ \\
\hline $\mathrm{t}$ & & $3.808^{* * *}$ & $3.528^{* * *}$ & $2410^{*}$ \\
\hline
\end{tabular}

$$
\begin{gathered}
* * *=\mathrm{p}<0.001 \\
*=\mathrm{p}<0.05
\end{gathered}
$$

Tablo-2. Bakarkör Buzağı ve Normal Danalarda Karaciğer, Zn, Cu ve Mn Ortalama Düzeyleri (ppm).

Table-2. The average liver $\mathrm{Zn}, \mathrm{Cu}$ and $\mathrm{Mn}$ levels in normal and blindness calves.

\begin{tabular}{|c|c|c|c|c|}
\cline { 5 - 5 } \multicolumn{1}{c|}{} & $\mathrm{n}$ & $\mathrm{Xn}$ & $\mathrm{Cu}$ & $\mathrm{Mn}$ \\
\hline Bakarkör Buzağı & 10 & $61.34 \pm 12.989$ & $\mathrm{X} \pm \mathrm{Sx}$ & $\mathrm{X} \pm \mathrm{Sx}$ \\
\hline Normal Dana (NIĞDE) & 7 & $37.8 \pm 3.235$ & $27.386 \pm 3.476$ & $5.42 \pm 0.106$ \\
\hline
\end{tabular}


Tablo 3. İz elcment düzeyleri arasınadaki ilişkiler

Table 3. The interrelations of the levels of trace elements between liver and serum in normal and blindness calves.

\begin{tabular}{|l|l|l|l|l|l|l|l|l|}
\cline { 2 - 9 } & \multicolumn{4}{|c|}{ Serum } & \multicolumn{4}{c|}{ Karaciğer } \\
\cline { 2 - 9 } & \multicolumn{2}{|c|}{ Bakarkör $\mathrm{n}=39$} & \multicolumn{2}{c|}{ Normal $\mathrm{n}=15$} & \multicolumn{2}{c|}{ Bakarkör $\mathrm{n}=10$} & \multicolumn{2}{c|}{ Normal $\mathrm{n}=7$} \\
\cline { 2 - 9 } & $\mathrm{Cu}$ & $\mathrm{Mn}$ & $\mathrm{Cu}$ & $\mathrm{Mn}$ & $\mathrm{Cu}$ & $\mathrm{Mn}$ & $\mathrm{Cu}$ & $\mathrm{Mn}$ \\
\hline $\mathrm{Zn}$ & $0.358^{*}$ & -0.103 & $0.6^{*}$ & -0.101 & 0.6 & 0.191 & 0.009 & 0.577 \\
\hline $\mathrm{Cu}$ & - & 0.048 & - & 0.241 & - & 0.155 & - & 0.155 \\
\hline
\end{tabular}

$*=p<0.05$

Tablo 4. Bakarkör Hayvanlara Ait Serum ve Karaciğer lz Element Düzeyleri Arasındaki Ilişkiler.

Table 4. The interrelation of the levels of trace elements between liver and serum in blindness calves

\begin{tabular}{|c|c|c|c|c|}
\cline { 4 - 5 } \multicolumn{1}{c|}{} & $\mathrm{n}$ & $\overline{\mathrm{Zn}}$ & $\mathrm{Cu}$ & $\overline{\mathrm{X}} \pm \mathrm{S} \overline{\mathrm{x}}$ \\
\cline { 2 - 5 } & 10 & $1.22 \pm 0.10$ & $\overline{\mathrm{X}} \pm \mathrm{S} \overline{\mathrm{x}}$ & $\overline{\mathrm{X}} \pm \mathrm{S \overline {x }}$ \\
\hline Scrum & 10 & $61.34 \pm 13.0$ & $86.39 \pm 17.1$ & $5.62 \pm 0.16$ \\
\hline Karaciğer & $\mathrm{r}$ & -0.292 & -0.357 & -0.0005 \\
& & Ö.D. & Ö.D. & O.D. \\
\hline
\end{tabular}

Ö.D.= Önemli değil

(non significant)

Tablo 5. Bakarkör Buzağılarda Serum tz Element Düzeyleri Sıklık Dağılımı.

Table 5. The distribution of serum trace elements levels in blindness calves.

\begin{tabular}{|c|c|c|c|c|c|}
\hline Serum Zn (ppm) & $\mathbf{n}$ & $\%$ & Serum $\mathrm{Cu}(\mathrm{ppm})$ & $\mathrm{n}$ & $\%$ \\
\hline$<0.5$ & 1 & 2.5 & $0.35-0.47$ & 4 & 10.3 \\
\hline $0.6-0.8^{*}$ & 10 & 25.6 & $0.48-0.59$ & 9 & 23 \\
\hline $0.9-1.1$ & 15 & 38.5 & $0.60 *-0.73$ & 7 & 18 \\
\hline $1.2-1.4$ & 8 & 20.5 & $0.74-0.86$ & 8 & 20.4 \\
\hline $1.5-1.7$ & 3 & 7.7 & $0.87-0.99$ & 7 & 18 \\
\hline $1.8<$ & 2 & 5.1 & $1.00-1.13$ & 4 & 10.3 \\
\hline Toplam & 39 & 100 & Toplam & 39 & 100 \\
\hline
\end{tabular}




\section{Tartışma ve Sonuç}

Rasyonel hayvan beslemenin gereği olarak iz elementlerin hayvanlar tarafından yeterli ve dengeli olarak alınmasının sağlanması kadar organizmanın iz element durumunun devamlı kontrol edilmesi de önemlidir.

Niğde ve çevresinde bakarkör buzağı doğumlarına sıklıkla rastlanmaktadır. Bozukluğun, kronik nitrat toksikasyonuna bağlı olarak şekillenen bir hipovitaminoz A ile ilişkili olduğu bir başka çalışma ile saptanmıştır (1). Vitamin A yetersizliği tespit edilmiş olan bu hayvanlar üzerinde yapılan ve çalışmamızın bir kısminı teşkil eden iz element analizleri sonucunda serum $\mathrm{Zn}$ ve $\mathrm{Cu}$ düzeylerinde önemli derecede $(p<0.001)$ bir düşüş, buna karşılık serum Mn değerlerinde ise önemli derecede $(p<0.05)$ bir artış kaydedilmiştir (Tablo 1).

Serum $\mathrm{Zn}$ ortalama değeri normal buzağılarda $1.507 \pm 0.133$ ppm ve bakarkör buzağılarda $1.054 \pm 0.053 \mathrm{ppm}$ olarak hesaplanmıştır. Gruplararası fark önemli bulunmuştur $(\mathrm{p}<0.001)$.

Serum $\mathrm{Zn}$ düzeylerindeki bu düşüşün hipovitaminoz A ile ilgili olabileceği görüşündeyiz. Çünkü deneysel hipovitaminoz A oluşturulan civcivlerde buna bağlı ikincil bir $\mathrm{Zn}$ yetersizliği meydana geldiği bildirilmektedir. Vit-A yetersizliğine bağlı olarak barsak mukozasında Zn emilimi azalmakta ve serum $\mathrm{Zn}$ konsantrasyonları düşmektedir. Retinil asetat ilavesiyle $\mathrm{Zn}$ emilimi tam olarak normale dönmektedir (3).

Çinko emiliminde Vitamin A gerekli olduğu gibi, vitamin A'nın karaciğerden mobilizasyonunda ve normal kan düzeylerinin sürdürülmesinde de $\mathrm{Zn}$ gereklidir $(4,11,32)$.

Buzağılar için serum Zn'sunun normal değeri 0.8-1.2 ppm olarak verilmektedir (37). Bir diğer çalışmada (14) normal buzağı serum Zn değeri $1.66 \mathrm{ppm}$ olarak bildirilmiştir. Niğde bölgesinden temin edilen sağlıklı buzağı serum Zn ortalama değerleri (Tablo-1) Hutcheson (14)'un verileriyle uyum içindedir. Bulunan değerler (Tablo-1) Underwood (37)'un verilerinden biraz yüksektir. Bu farklılıklar beslenme, yaş, iklim, ırk, cinsiyet gibi faktörlerden kaynaklanabilir $(21,22)$.

Sığırlarda, Zn yetersizliği için verilen serum Zn kritik değerleri (0.6-0.8 ppm) gözönüne alındığında (20), bakarkör buzağıların \%25.6'sının bu sınırlar içinde kaldığı dikkati çekmektedir (Tablo-5). Buradan hareketle söz konusu hayvanlarda bakarkörlük $\mathrm{Zn}$ yetersizliği için bir risk faktörü olarak değerlendirilebilir. Çünkü bakarkör hayvanların yemden yararlanma oranlan düşük ve kondisyonlan bozuktur (1).

Çalışmamızda serum $\mathrm{Cu}$ ortalama değerleri normal buzağılarda $0.951 \pm 0.051 \mathrm{ppm}$ ve bakarkör buzağılarda $0.731 \pm 0.033 \mathrm{ppm}$ olarak hesaplanmıştır. Gruplararası fark önemlidir $(p<0.001)$. Serum $\mathrm{Cu}$ düzeylerindeki bu 
düşüşün bakarkör hayvanlarda Zn emilimindeki azalmanın $\mathrm{Cu}$ emilimi üzerine olumsuz etkisiyle $(7,11,24)$ olabileceği düşünülebilir.

Hipovitaminoz A ile ilgili Zn emiliminin azalması, normal bir beslenme durumunda bile barsak lümeninde $\mathrm{Zn}$ birikimini düşündürebilir ve rasyonla fazla $\mathrm{Zn}$ alınıyormuş gibi diğer elementlerin emilimi üzerine (bilhassa $\mathrm{Cu}$ ) olumsuz etki yapabilir. Nitekim, $Z$ n düzeyi yüksek rasyonla beslenen ruminantlarda Cu emiliminin önemli düzeyde düştüğü saptanmıştır (11).

Rasyonda belirli bir $\mathrm{Cu} / \mathrm{Zn}$ oranının sağlanması gerektiği bilinmekte (24) ve bu oran ruminantlar için $1 / 10$ olarak önerilmektedir (7).

Gerek bakarkör gerekse normal hayvanlarda serum $\mathrm{Zn}$ ve $\mathrm{Cu}$ düzeyleri arasında önemli derecede ( $\mathrm{p}<0.05$ ) pozitif bir korrelasyon saptanmıştır. Ancak korrelasyon katsayıları gözönüne alındığında ilişkinin bakarkörlerde oldukça zayıfladığı görülmektedir (Tablo 3). Bu da bakarkörlükte azalan $\mathrm{Zn}$ emiliminin Cu'ın emilimini azaltabileceği yönündeki görüşümüzü desteklemektedir.

Buzağılar için serum Cu'ının normal değeri 0.790 .24 ppm olarak verilmiştir (19). Hutcheson (14) ise bu değeri 1.03 ppm olarak bildirmiştir. Yöreden sağladığımız sağlıklı buzağı serumlarının $\mathrm{Cu}$ ortalama düzeyleri (Tablo-1) yukarda belirtilen literatür değerler arasında yer almaktadır. Beslenme, yaş, bölge, ırk vb. faktörlerin düzeylerde farklılıklara yol açabileceği $(21,22)$ unutulmamalidir.

Sığırlarda $\mathrm{Cu}$ yetersizliğinden sözedebilmek için serum $\mathrm{Cu}$ düzeylerinin, kritik değer olan 0.6 ppm'in altına düşmesi gerekir (7). Çalışmamızda bakarkör buzağılardan \%33.3'ünde serum $\mathrm{Cu}$ düzeyleri bu değerin altındadır (Tablo-5). Buradan hareketle, bakarkörlüğün $\mathrm{Cu}$ yetersizliğine de predispoze bir ortam hazırladığı sonucu çıkarılabilir.

Bakarkör ve normal buzağılarda serum Mn ortalama düzeyleri sırasıyla $0.135 \pm 0.01 \mathrm{ppm}$ ve $0.088 \pm 0.017 \mathrm{ppm}$ olarak tespit edilmiştir. Gruplar arası fark önemli ( $\mathrm{p}<0.05$ ) bulunmuştur. Serum Mn düzeylerindeki artış oranı \%53 olarak hesaplanmıştır.

Ruminantların Mn homeostasisinde endojen atılım absorbsiyondan daha önemli bir role sahiptir ve Mn'ın en önemli atılım yolu safradır $(6,23,26)$. Karaciğerden safra sekresyonu safra asitlerinin koleretik etkisiyle düzenlenir. Safra asitleri ise kolestrolden sentezlenir (6). Hipovitaminoz A durumlannda kolesterol sentezi bloke edilir (35). Bu bilgiler ışığında bakarkör buzağılarda serum Mn düzeylerindeki artışın hipovitaminoz $\mathrm{A}$ ile ilgili olduğu söylenebilir.

Dana ve buzağılar için serum Mn mormal değeri 0.02 ppm olarak bildirilmiştir (37). Bir başka literatürde (11) bu değer ruminantlar için 0.02-0.1 ppm olarak verilmiştir. Bölgeye ait normal buzağı serum ortalama düzeyleri literatïrlere uygun bulunmuştur (Tablo-1). 
Yöreye ait bakarkör buzağ 1 larda, karaciğer $\mathrm{Zn}, \mathrm{Cu}$ ve $\mathrm{Mn}$ ortalama değerleri sırasıyla $61.34 \pm 12.989,86.39 \pm 17.123$ ve $5.62 \pm 0.165 \mathrm{ppm}(\mu \mathrm{g} / \mathrm{g}$ yaş ağırlık) olarak saptanmıştır. Bu değerlerin istatistik karşılaş̧ırılabilmesi için gerekli olan normal buzağı karaciğer örnekleri gerek üreticilerin sağlıklı buzağılarını satmak istememesi gerekse normal buzağı kesiminin yurdumuzda yasak olması gibi nedenlerden dolayı temin edilememiştir. Buna karşılık yöredeki normal hayvanların karaciğer iz element düzeyleri hakkında bir fikir edinebilmek için Niğde mezbahasından temin edilen 7 adet 1-2 yaşlı normal danalara ait karaciğer örneklerinde $\mathrm{Zn}, \mathrm{Cu}$ ve $\mathrm{Mn}$ analizleri yapılmuştır. Bu danalara ait karaciğer $\mathrm{Zn}$, $\mathrm{Cu}$ ve $\mathrm{Mn}$ ortalama değerleri sırasıyla $37.8 \pm 3.235,27.386 \pm 3.476,5.42 \pm 0.106$ $\mathrm{ppm}(\mu \mathrm{g} / \mathrm{g}$ yaş ağırlık) olarak tespit edilmiştir. Buzağı ve danalara ait karaciğger Zn ve Cu ortalama değerlerine bakıldığında buzağı karaciğeri iz element düzeylerinin danalara oranla hayli yüksek olduğu gözlenmektedir (Tablo-2). Bunun hayvanlardaki yaş ve canlı ağırlık artışı faktörlerine bağı olabileceği düşünülmektedir. Çünkü, $\mathrm{Zn}$ emiliminin yenidoğanlarda yetişkinlerden daha fazla olduğu (16) ve buzağılarda doğum sırasında yüksek olan karaciğer $\mathrm{Cu}$ düzeylerinin yaşın ilerlemesi ve canlı ağırlık artışına bağlı olarak düştüğü (9) bildirilmektedir.

Buzağılar için karaciğer $\mathrm{Zn}$ normal değeri $25-50$ ppm olarak verilmiştir (15). Çalışmamızın materyallerinden olan bakarkör buzağılarda karaciğer $\mathrm{Zn}$ ortalama düzeyleri (yöreye ait normalleri olmadığından) bu literatür değeri ile karşılaştırıldığında yöreye ait değerlerin yüksek olduğu ortaya çıkmıştır. Karşılaştırılan değerler arasındaki yöresel, mevsimsel, besinsel ve bireysel farklılıklara rağmen artışın bakarkörlük ile ilişkili olabileceği söylenebilir.

Buzağılar için karaciğer Cu normal değeri $35-200) \mathrm{ppm}$ arasında bildirilmiştir (15). Bölgedeki bakarkör buzağılardan elde edilen karaciğer örneklerinde $\mathrm{Cu}$ ortalama değerleri $86.39 \pm 17.123$ ppm olarak tespit edilmiştir (Tablo-2). Bu değer literatürde bildirilen normal sınırlar içerisinde kalmaktadır.

Niğde mezbahasından temin edilen dana karaciğer $\mathrm{Zn}$ ve $\mathrm{Cu}$ ortalama değerleri (Tablo-2), Korsrud ve ark. (17)ın Kanada'da gerçekleştirdikleri çalışmadaki $\mathrm{Zn}(45.1 \pm 16.7 \mathrm{ppm})$ ve Cu $(27.8 \pm 26.7 \mathrm{ppm})$ ortalama değerleri ile uyum içindedir.

Ankara Et-Balık Kombina'sından temin ettiğimiz 1-2 yaşlı normal danalara ait karaciğer örneklerinde $\mathrm{Zn}$ ve $\mathrm{Cu}$ ortalama değerleri sırasıyla $52.32 \pm 16.86$ ve $59.63 \pm 18.86 \mathrm{ppm}(\mu \mathrm{g} / \mathrm{g}$ yaş ağırlık) olarak hesaplanmıştır. Bu değerler gözönüne alındığında Niğde yöresine ait sağlıklı danaların karaciğer $\mathrm{Zn}$ ve Cu düzeylerinin belirgin şekilde düşük olduğu görülmektedir. Bu farklılığın beslenme, ırk, cinsiyet ve çevre faktörleri yanında $(14,21,22)$, Niğde bölgesine özel bazı faktörlerin etkisiyle de gelişebileceği düşünülebilir. Çünkü yörede hayvanlara ad libitum verilen patates bitkisinin kök, sap ve yumrularında yüksek nitrat varlığı tespit edilmiştir (42). Gerek bitkilerin kök, sap ve yumrularındaki fitatların $(11,16)$ gerekse nitratların $(15)$ minerallerden yararlanma üzerine olumsuz etki yapabileceği bilinmektedir. 
Yöreye ait buzağı ve dana karaciğer Mn düzeyleri arasında ise belirgin bir farklılık göze çarpmamaktadır (Tablo-2). Bu sonuç, literatür bilgiler ışığında normal bir durum olarak değerlendirilebilir. Çünkü, yeni doğan buzağıların karaciğerinde Cu'ın aksine yedek Mn depolanması söz konusu değildir ve karaciğer Mn düzeyleri yaş ve tür gibi faktörlere bağlı olarak çok az değişim gösterir (37).

Sonuç olarak, bölgede önemli bir problem oluşturan bakarkörlük (Amaurosis) olgularında serum $\mathrm{Zn}$ ve $\mathrm{Cu}$ düzeylerinin önemli derecede $(\mathrm{p}<0.001)$ düştügüi, Mn düzeylerinin ise önemli derecede $(\mathrm{p}<0.05)$ yükseldiği tespit edilmiş ve bu değişikliklerin hayvanlarda varlığı tespit edilen Vit-A yetersizliğinin de esas nedenini teşkil eden nitrat ve nitrit ile muhtemelen fiatlardan zengin olan patates bitkisinin kök, yaprak ve yumrularıyla hayvanların ad libitum beslenmesinden kaynaklanabileceği görüşüne varılmıştır. Dolayısıyla bu bitkinin değişik kısımlarının rasyondan ya tamamen çıkarılması ya da sınırlı bir şekilde verilmesi yanında hayvanlarda kan mineral analizlerinin belirli zamanlarda tekrarlanarak vücut mineral durumunun izlenmesinin gerektiğinde yetersiz gebelerin vit-A ile birlikte $\mathrm{Zn}$ ve $\mathrm{Cu}$ yönünden de takviyelerinin yararlı olacağı kanaatine varılmıştur.

\section{Kaynaklar}

1. Altıntą̧ A., Maraşlı, Ş., Varol, H.H. (1993): Kapadokya bölgesindeki buzağtlarda görülen Amaurosis'de kanda vit-A, $\beta$-kurotin, $T_{3}$ ve $T_{4}$ düzeyleri. TÜBITAK, VHAG-899 nolu proje.

2. Amer, A.A.: Raghib, M.F.: Gazia N.: Salim, H.A.: El-Newavi, F.; Abdel-Monim. M. (1982): The effect of dietary vitamin A deficiency on the clinical condition, blood constituents and internal organs of adult boffaloe. Assiut Vet. Med. J. 9: 17-18, 137-140.

3. Berzin, N.I.; Bauman, V.K. (1987): Vitamin A dependent zinc-binding protein and intestinal absorption on $\mathrm{Zn}$ in chicks. Brit. J. Nutr. 57. 255-268.

4. Booth, A.; Reid, M; Clark, T. (1987): Hypovitaminosis A in feedlot cattle. JAVMA, 190: $101305-1308$.

5. Divers, T.J.; Blakmon, D.M.; Martin, C.L., Worrel, D.E. (1986). Blindness and convilsions associated with vitamin A deficiency in feedlot steers. JAVMA, 189: 12, 1579-1582.

6. Ersoy, E.; Bayşu, N. (1986): Biyokimya, Ankara Üniversitesi Veteriner Fakültesi Yayınları No: 408. Ankara Üniversitesi Basimevi, Ankara, pp.333, 620.

7. Faye, B.; Grillet, C. (1984): La carance en cuivre chez les ruminants domestiques de la region d'Awaash (Ethiopie). Rev. Elev. Med. Vet. Paystrop, 37: 1, 42-60.

8. Ghanem, Y.S.; Farid, M.F.A. (1982): Vit-A deficiency and supplementation in desert sheep. I. Deficiency symptoms, plasma concentrations and body growth. World-Review of animal Production, 18: 2, 69-74.

9. Grift, J. Van Der (1955): Het kopergehalte van lever en blaedserum bij het fries-hollandse rund. Inaugural-Dissertation. S-Gravenhage, 1955.

10. Handerson, J.A. (1957): Conditioned copper deficiency in canadian cattle. Canad. J. Comp. Med. 21: 332-335. 
11. Hansard, S.L. (1983): Microminerals for ruminant animals. Nutrition Abstracts and Reviews-Series B, vol: 53, No:1.

12. Hazıroğlu, R.: Kutsal, O.; Maraşlı, N.; Altıntaş, A.; Özgencil, E.; Yavuz, H. (1993): Nevşehir, Niğde, Aksaray illeri ve çevrelerinde buzağılarda görülen Amaurosis olaylarında patolojik bulgular. TÜBITAK, VHAG-927 No'lu proje.

13. Hintz, H.F.: Schryver, H.F. (1976): Nutrition and bone development in horses. JAVMA 168: $1,39-44$.

14. Hutcheson, D.P. (1987): Minerals for feedlot Cattle. Agri-practice-Bovine Nutrition. 8: 3, 3 6.

15. Johnson, J.L.: Schneider N.R.: Slanker M.R. (1989): Trace element concentrations in perinatal beef calves from West Central Nebraska. Vet. Hum. Toxical 31: 6, 521-525.

16. Keen, C.L.; Graham, T.W. (1989): Trace elements. In: Kaneko, J.J. Clinical Biochemistry of Domestic Animals. 4th.Ed. Acad. Press. Inc. USA, pp: 753-784.

17. Korsrud, G.O.; Meldrum, J.B.; Salisbury, C.D.; Houlahan, B.J.; Saschenbrecker, P.J.; Tittiger F. (1985). Trace element levels in liver and kidney from cattle, swine and poultry slaughtered in Canada. Can. J. Comp. Med. 49: 159-163.

18. Kutsal, A.; Alpan, O.; Arpacık, R. (1990): Istatistik Uygulamalar. Ankara, Bizim Büro Basımevi.

19. Long, C. (1961): Biochemists' Handbook, 1st Ed. E \& F.N. Spond Ltd. pp: 1192. London.

20. McDowell, L.R.; Conrad, J.H. (1989): Detection of mineral deficiencies and toxicities for grazing livestock. In: Yüregir, T.G. Trace elements in health and disease. Trace ' 89 Proceedings of the 3rd International Congress on Trace Elements in Health and Disease at Adana (Turkey). March 31-April 8. pp: 69-81.

21. McDowell, L.R.; Conrad, J.H.; Ellis, G.L. (1985): Ruminant mineral deficiencies and radioisotopic and other techiniques of detection. FAO/LAEA Conference on Research Using Nuclear Techniques and Aimed at Improving Meat, Milk and Wool Production from Ruminant Animals. June 3-8, 1985. Ankara-Turkey.

22. McDowell, L.R.; Conrad, J.H.; Ellis, G.L. (1985): Mineral supplemantation for grazing Ruminants. FAO/IAEA Conference on Research Using Nuclear Techniques and Aimed at Improving Meat, Milk and Wool production from Ruminant animals June 3-8, 1985, AnkaraTurkey.

23. Miller, W.J. (1973): Dynamics of absorption rates, endogenous excretion, tissue turnover, and hemostatic control mechanisms of zinc, cadmium, manganese, and nickel in ruminants. Federation Proc. 32: 1915-1920.

24. Parry, W.H.; Jackson, P.G.G.; RaO, S.R.R.; Cooke, B.C. (1985): Effects of high dietary Zinc on Cooper transport in three breeds of housed pregnant sheep. In: Trace Elements in Man and Animals (Editors: C.F. Mills, I. Bremner and J.K. Chesters) P.376-378. Commonwealth. Agricultural Bureaux U.K.

25. Prasad, A.J. (1976): Trace elements in human health and disease. Volume: I Zinc and Copper, pp: 155, 409-410, Acad. Pres. Inc. New York. 
26. Prasad, A.J. (1976): Trace elements in human health and disease. Volume: II Essential and toxic elements pp: 345. Acad. Pres. Inc. New York.

27. Richter, G.H.; Flachowsky, G.; Ochrimenko, W.I.; Geinitz, D. (1989): Influence of Ca and $\mathrm{Zn}$ supply on vit-A status of bulls. In 6th International Trace Element. Symposium Vol: $2,652-658$.

28. Rucker, R.B.; Parker, H.E.; Rogler, J.C. (1969): Effect of cooper deficiency on chick bone collagen and selected bone enzymes. J. Nutrition, 98: 57-63.

29. Sağkal, S. (-): Hayvan beslemede iz elementler. TÜBITAK Bilgi profili No: 55.

30. Schone, F. (1986): Factors influencing vitamin A balance with particular reference to growing pigs. Monatshefte-für-Veterinarmedizin. 41: 12, 401-405.

31. Shlosberg, A.; Egyed, M.N.; Eilat, A. (1977): Severe hypovitaminosis A in two herds of beef calves. Refuah-Veterinarith, 34:1 25-27.

32. Smith, J.C. Jr.; McDaniel, E.G.; Fan, F.F.; Halsted, J.A. (1973): Zinc: a trace element essential in vitamin A metabolism. Science, 181: No.4103, 954-955.

33. Spratling, F.R. (1976): Complex nutritional deficiency in a group of calves. Brit. Vet. J. 132: 6, 557-567.

34. Sanl, Y.: İmren, H.Y.; Kaya, S.; Koç, B.; Kahraman M. (1983): Isparta yöresinde doğmus buzağılarda gïrülen amorozis olguları ile gebe ineklerde karşılaşılan kronik nitrat zehirlenmeleri arasindaki ilişkilerin incelenmesi. A.Ü. Vet. Fak. Derg., 30: 4, 657-673.

35. Tiftik, A.M. (1990): Konya bölgesinde, sağlıklı ve hastalıklı buzağı ve sı̆̆ırlarda kan plazmast $\beta$-karotin, vit-A düzeylerinin tespiti ve bu düzeylerle hastaliklar arastndaki iliskilerin araşıırılmast. Doktora tezi. Selçuk Üniversitesi Sağlık Bilimleri Enstitüsü.

36. Tojo, H.; Kinoshita, S.; Sato, Y.; Saruta, K.; Oota, T.; Takada, F. (1988): Vitamin A deficiency in fattening Japanese black cattle. J. of the Japan Veterinary-Medical Association. $41: 2,108-113$.

37. Underwood, E.J. (1977): Trace elements in human and animal nutrition. 4th edn. London. U.K. Acad. Press. Inc. pp.: xii +545 .

38. Urman, H.K. (1966): Kuzulurda enzootik ataksi hastalığı üzerinde patolojik araştırma. A.Ü. Vet. Fak. Derg. 13: 4, 329-353.

39. Van Loon, J.C. (1980): Analitical Atomic Absorption Spectroscopy, Selected Methods, Acad. Press. New York. pp: 158-219.

40. WHO, (1984): Strategies for the prevention of blindness in national programmes a primary health care approach. Geneva.

41. Widdowson, E.M.; Dauncey, J.; Shaw, J.C.L., (1974): Trace elements in foetal and early postnatal development. Proc. Nutr. Soc. 33, 275-284.

42. Yavuz, H.; Kaya, S.; Altıntaş, A.; Maraşlı, S. (1994): Nevşsehir ve Niğde yöresinden sağlanan toprak ve su örnekleri ile yemlik olarak kullanilan patates bitkisinin çeşitli kısımlarında nitrat ve nitrit düzeyleri. A.Ü. Vet. Fak. Derg. 4l(1): 107-118. 